\title{
Anti-IgG Agglutinins in Idiopathic Respiratory Distress Syndrome of the Newborn
}

\author{
GWENDOLINE HARDIE and J. E. KENCH \\ From the Department of Physiology and the C.S.I.R. Protein Research Unit, Department of Chemical Pathology, \\ University of Cape Town, South Africa
}

In our previous studies (Hardie, Heese, and Kench, 1965; Hardie, Harrison, and Kench, 1968) on the serum proteins of infants suffering from the idiopathic respiratory distress syndrome of the newborn (IRDS), we found that affected infants had a significantly lowered concentration of total serum proteins, a marked relative decrease in the concentration of $\gamma-G$ globulins (IgG), and a raised concentration of the $a$-fetoprotein described by Gitlin and Boesman (1966), as compared with a control group of healthy premature infants of the same mean gestational age. The concentration of serum IgG fell, on average, more rapidly during the first 24 hours after birth in infants with IRDS than in normal infants (Hardie et al., 1965). We observed also (Hardie and Kench, 1967) that mothers of infants with IRDS had, in late pregnancy and shortly after childbirth, significantly lower concentrations of serum IgG than had mothers of healthy premature infants. Concentrations of total serum proteins of the mothers of affected infants, however, were within normal limits. The urine and faeces of the infants with respiratory distress and of their mothers were examined for content of IgG. Our observations excluded the possibility that IgG was being lost from the circulation via the kidneys or by the alimentary canal.

Specimens of oedema fluid obtained from some of the infants contained $2-3 \mathrm{~g}$. protein $/ 100 \mathrm{ml}$., of which more than $90 \%$ was albumin.

As we were interested in the possibility that there might be an immune reaction occurring between mothers and their infants which could account for the low IgG concentrations observed, it was decided to examine the sera of these infants for antibodies against their mothers' IgG.

\section{Materials and Methods}

Venous blood was taken at birth from the umbilical

Received May 20, 1969. cord of 35 healthy, premature infants and of 28 infants who, within a few hours of birth, developed signs of respiratory distress, for which no obvious cause could be found. The clinical diagnosis of IRDS was made in infants manifesting any of the signs of respiratory distress-tachypnoea, cyanosis in room air, laboured respiration with rib recession, expiratory grunting. The diagnosis was confirmed for 11 of the infants by the characteristic chest $x$-ray picture: viz. 'ground glass' opacity of the lung fields with an air bronchogram. Blood gas and acid-base data were collected on 10 of the 11 infants in this group (Table I), and these indicate the presence of severe respiratory impairment. Detailed clinical and blood-gas data were not available for the eleventh infant in this group, but the diagnosis was confirmed at necropsy. In the remainder (17 infants), the diagnosis was made clinically, chest $x$-ray being precluded by severity of the illness or lack of facilities. This latter group included 8 very immature infants (gestational age less than 32 weeks), some of whom may not have been true cases of IRDS. These are labelled IRDS? in Table II. The data on these infants appeared important to us as they indicate that prematurity alone is not responsible for IRDS. Followup specimens of blood were obtained from a peripheral vein at the age of a few weeks from 4 cases of IRDS and 2 healthy premature infants. Sera were stored at $4^{\circ} \mathrm{C}$. with $0.1 \% \mathrm{w} / \mathrm{v}$ sodium azide as a preservative. The concentration of total serum proteins was determined by the biuret method (Gornall, Bardawill, and David, 1949), and the concentrations of IgG and IgM in the sera of the infants were measured by a radial immunodiffusion technique (Immunoplates: Hyland laboratories). Concentrations of IgA were not determined as they were too low to produce adequate precipitin rings on the agar plates. For the detection, in the infants' sera, of antibodies against the maternal IgG, the experimental procedure was as follows.

Sheep red blood cells, preserved in Alsever's solution, were formalinized by the method of Csizmas (1960). For each mother-and-child pair, IgG was prepared from the maternal serum by initial precipitation of most of the other serum proteins with $0.4 \% \mathrm{w} / \mathrm{v}$ rivanol at $p \mathrm{H} 9 \cdot 4$ (Kistler et al., 1960), after which the rivanol was removed by precipitation with $\mathrm{KBr}$. IgG was precipitated from the resulting supernatant solution by adjusting the $\mathrm{pH}$ to 6.8 and adding ethanol at 
TABLE I

Clinical, Biochemical, and Necropsy Findings on Infants with Confirmed IRDS

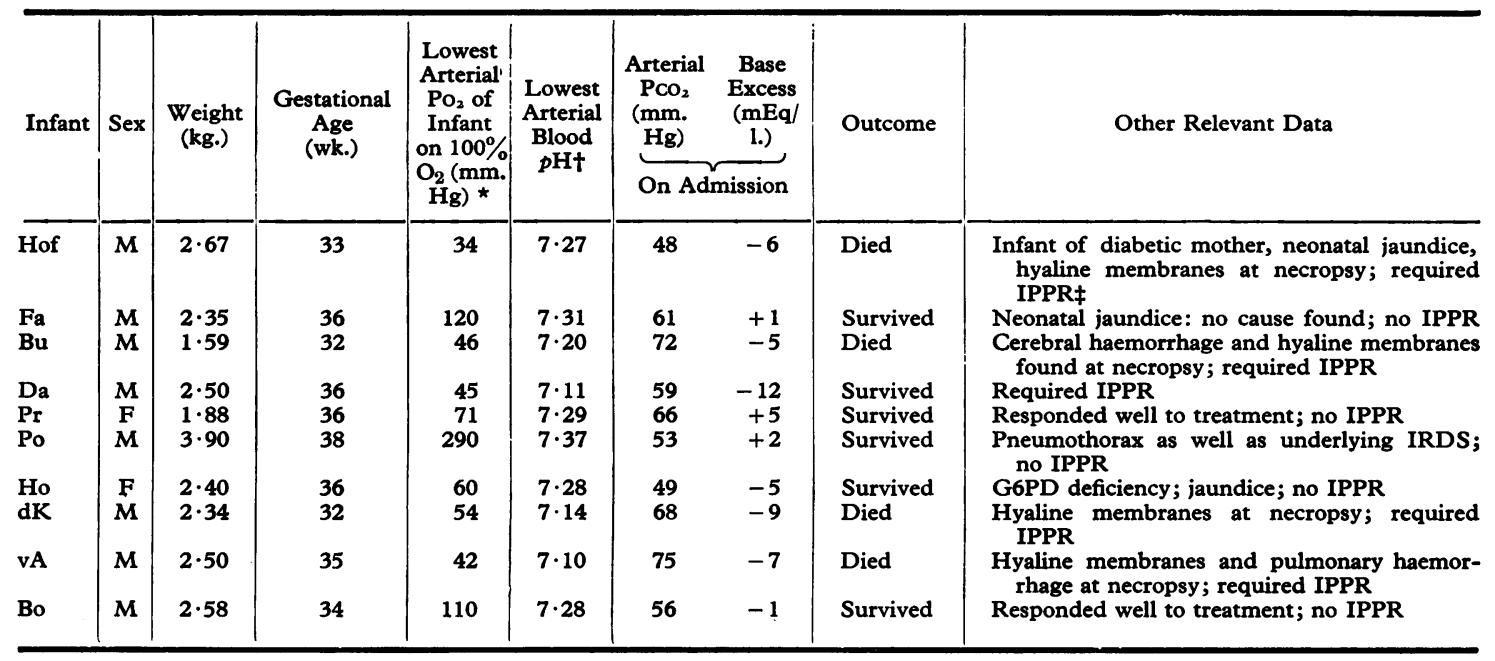

$\star$ Blood samples for these data were obtained through an indwelling catheter passed via an umbilical artery into the abdominal aorta. Lowest arterial $\mathrm{PO}_{2}$ of infants given $100 \% \mathrm{O}_{2}$ occurred at variable times after birth, usually at about 36 hours of age.

† Blood $p \mathrm{H}$, arterial $\mathrm{PCO}_{2}$ and base excess were measured after intravenous therapy with $2 \cdot 0 \mathrm{mEq} \mathrm{NaHCO} / \mathrm{kg}$. body weight had begun. ¥ IPPR - treatment with intermittent positive pressure respirator.

\section{TABLE II}

Mean Gestational Age, Protein Concentrations, and Mean Anti-IgG Titres ( $\pm S E$ ) in Three Groups of Infants

\begin{tabular}{|c|c|c|c|c|c|c|}
\hline Group & $\begin{array}{c}\text { No. of } \\
\text { Cases }\end{array}$ & $\begin{array}{c}\text { Mean } \\
\text { Gestational } \\
\text { Age (wk.) }\end{array}$ & $\begin{array}{c}\text { Total Serum } \\
\text { Protein } \\
\text { (g. } / 100 \mathrm{ml} .)\end{array}$ & $\begin{array}{c}\text { IgG } \\
(\mathrm{g} . / 100 \mathrm{ml} .)\end{array}$ & $\begin{array}{c}\mathrm{IgM} \\
(\mathrm{mg} \cdot / 100 \mathrm{ml} .)\end{array}$ & $\begin{array}{l}\text { Mean Anti- } \\
\text { IgG titre } \\
\text { (dilution) }\end{array}$ \\
\hline $\begin{array}{l}\text { Normal prematures } \\
\text { IRDS? } \\
\text { Confirmed IRDS }\end{array}$ & $\begin{array}{l}35 \\
17 \\
11\end{array}$ & $\begin{array}{l}34 \cdot 1 \pm 0 \cdot 4 \\
32 \cdot 1 \pm 0 \cdot 6 \\
34 \cdot 6 \pm 1 \cdot 1\end{array}$ & $\begin{array}{l}4 \cdot 7 \pm 0 \cdot 02 \\
4 \cdot 1 \pm 0 \cdot 02 \\
3 \cdot 6 \pm 0 \cdot 35\end{array}$ & $\begin{array}{l}1.04 \pm 0.06 \\
0.64 \pm 0.08 \\
0.56 \pm 0.06\end{array}$ & $\begin{array}{l}12 \pm 1 \cdot 1^{\star} \\
8 \pm 1 \cdot 4 \\
8 \pm 0 \cdot 4\end{array}$ & $\begin{array}{l:l}1 & : 14 \\
1 & : 82 \\
1 & : 591\end{array}$ \\
\hline
\end{tabular}

* The normal premature group included one normal infant who had, atypically, an IgM concentration of $90 \mathrm{mg} . / 100 \mathrm{ml}$. This inflated the mean and standard error for this group.

$-5{ }^{\circ} \mathrm{C}$. to a final concentration of $25 \%$ by volume. This method gives a product that is pure on immunoelectrophoresis but lacks some of the faster-moving IgG (Fig. 1).

However, it retains its native immunological and biological properties (Hořejší and Smetana, 1956; Saifer and Lipkin, 1959). Determination of maternal IgG was done in each case by (i) the biuret method (Gornall et al., 1949) and (ii) immunoplates (Hyland). The mean of the two values was calculated and an appropriate dilution made.

Optimal conditions for tanning and coating the formalinized erythrocytes with maternal IgG (based on the method of Daniel, Weyand, and Stavitsky, 1963; Daniel and Stavitsky, 1964) were as follows.

(1) The erythrocytes were washed three times in $0.15 \mathrm{M} \mathrm{NaCl}$ and diluted in $0.15 \mathrm{M} \mathrm{NaCl}$ to make a $2 \cdot 5 \%$ suspension by volume.

(2) An equal volume of tannic acid solution $(0.5 \mathrm{mg} .1$
$100 \mathrm{ml} .0 \cdot 15 \mathrm{M} \mathrm{NaCl}$ ) was added and the mixture incubated for 10 minutes at $37^{\circ} \mathrm{C}$.

(3) The tanned cells were then washed once in phosphate-buffered $\mathrm{NaCl}(0 \cdot 15 \mathrm{M}, p \mathrm{H} \mathrm{7 \cdot 2)}$ and incubated for 30 minutes with maternal IgG $(100 \mu \mathrm{g} . / \mathrm{ml}$.) at $\mathrm{pH} 6 \cdot 5$.

(4) The tanned, coated cells were now washed three times with normal rabbit serum (NRS) previously heat-inactivated at $56^{\circ} \mathrm{C}$. for 30 minutes and diluted $1: 200$ in $0.15 \mathrm{M} \mathrm{NaCl}$.

(5) Finally, the sensitized cells were resuspended in an equal volume of NRS.

Before the titration, sera were absorbed with (i) uncoated tanned cells and (ii) uncoated, non-tanned cells $(0.05 \mathrm{ml}$. cells to $0.1 \mathrm{ml}$. serum diluted in $0.9 \mathrm{ml}$. NRS). The former destroyed the agglutinating activity of all but very high-titred sera. The latter had little or no effect.

Serial doubling dilutions of the infants' sera were made 


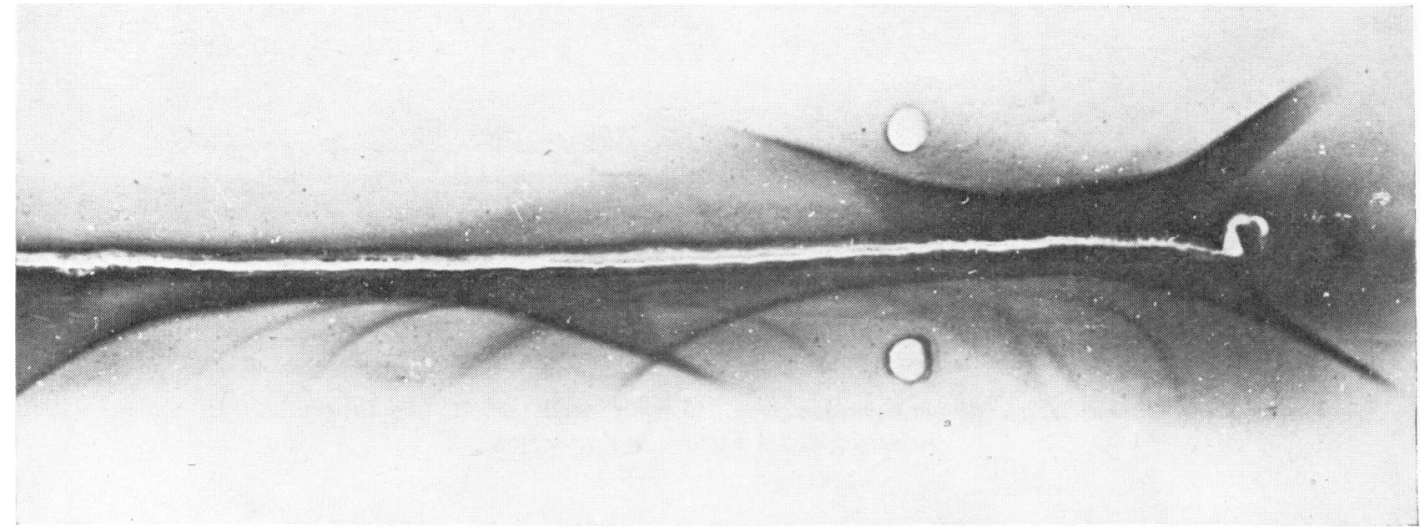

FIG. 1.-Upper well: IgG prepared from maternal serum by the rivanol-ethanol method. Lower well: whole maternal serum. In slot: polyvalent antiserum against whole human serum.

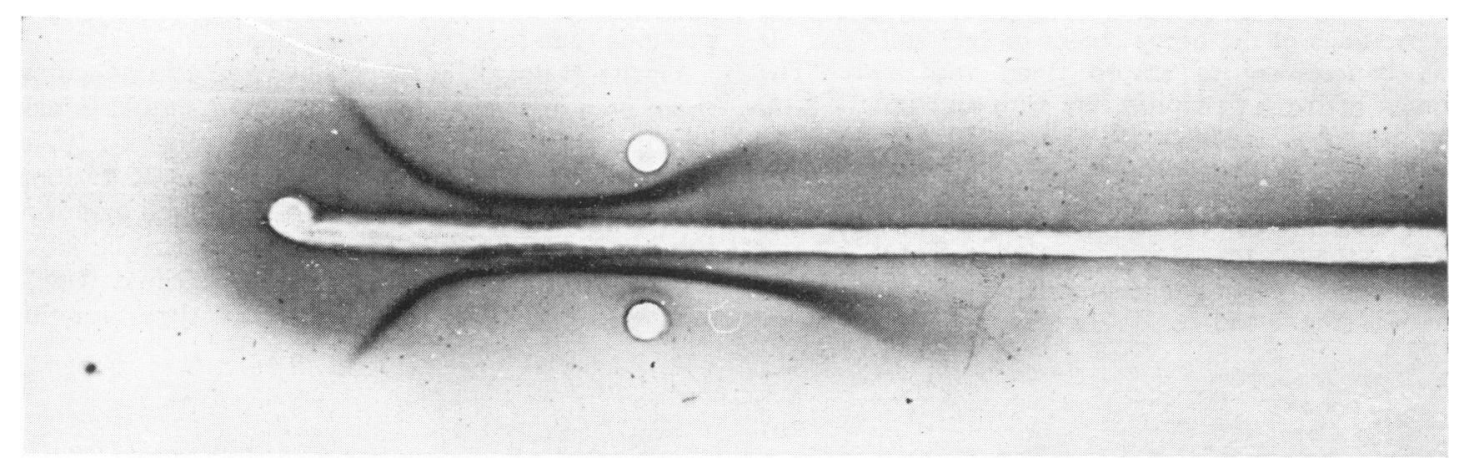

FIG. 2.-Upper well: IgG prepared from maternal serum by the rivanol-ethanol method. Lower well: whole maternal serum. In slot: monospecific antiserum against human IgG.

in a perspex haemagglutination tray, starting at a concentration of $1: 10.0 .05 \mathrm{ml}$. of the erythrocyte suspension coated with each infant's own mother's IgG was then added to each well and stirred to make an even suspension. Sera were not heat-inactivated to destroy complement as this is unnecessary when using formalinized cells. We have found that such cells are invariably extremely resistant to lysis and this is the experience of other workers (Daniel and Stavitsky, 1964; Cox, 1956; Moskowitz and Carb, 1957).

Controls were as follows:

(1) Coated cells in plain diluent.

(2) Coated cells titrated against a commercial antiserum to IgG. This antiserum was supplied by Hyland laboratories. It was observed to be monospecific by immunoelectrophoresis (Fig. 2) and free of soluble complexes (personal communication: Hyland laboratories, 1968).

(3) An inhibition titration duplicating the assay titration, but with $0.2 \mathrm{mg}$. of maternal IgG added to each well before introduction of the cells.
(4) An attempt was made to set up an additional control with formalinized, tanned, sheep's erythrocytes not coated with antigen. However, this was found to be unsatisfactory as these cells agglutinated with every serum against which they were titrated. Presumably, the mechanism is that such cells take up proteins from the serum, the protein molecules then forming bridges between the cells, resulting in agglutination.

Instead, formalinized tanned cells coated with human serum albumin (immunoelectrophoreticallypure: Fig. 3) provided a satisfactory control.

Titrations were allowed to settle overnight at room temperature, and agglutination was graded,,- \pm+ , ,+++++ , according to the diameter of the resulting agglutinate. In addition, tanned red blood cells were sensitized with Bence-Jones proteins of types $\mathrm{L}$ or $\mathrm{K}$. Bence-Jones proteins were isolated from the urine of patients with multiple myeloma and purified by preliminary precipitation with half-saturated $\left(\mathrm{NH}_{4}\right)_{2} \mathrm{SO}_{4}$, followed by column chromatography on DEAE cellu- 


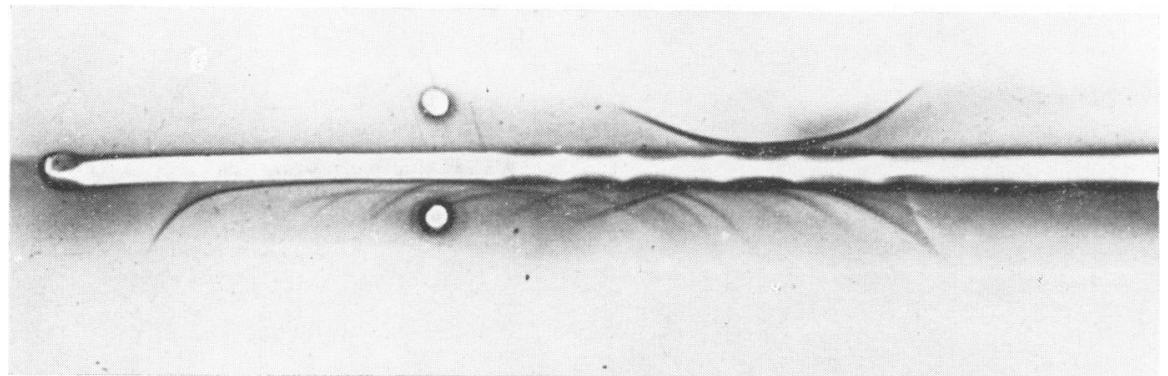

FIG. 3.-Upper well: human serum albumin preparation. Lower well: whole human serum. In slot: polyvalent antiserum against whole human serum.

lose. Fractions containing Bence-Jones protein were then subjected to gel filtration on Sephadex G100. The purity of these preparations was checked by means of Ouchterlony plates (Fig. 4 and 5). The antisera used in Fig. 4 were prepared by immunizing goats with preparations of the heavy chains of IgG and IgA. It was unnecessary to absorb them with Fab. The protein giving a precipitin line with anti-IgA (Fig. 4) was discarded. Other cells were coated with a papain digest of IgG prepared from pooled human serum. Papain digestion was performed for 18 hours at $37^{\circ} \mathrm{C}$. in the presence of cysteine (according to the method of Porter, 1959). The products included the usual 3 components (Fab, Fc) revealed on immunoelectrophoresis (Fig. 6 and 7).

\section{Results}

Observations on the infants' sera are presented in Table II. As can be seen, the IRDS group had a significantly lower concentration of total serum proteins than had the normal infants.

Of the 35 normal infants, 8 had agglutinins against their own maternal IgG coated on tanned sheep erythrocytes, the titres ranging from $1: 10$ to 1 : 128. The remaining 27 neonates had none. Among the 17 doubtful cases, 7 possessed agglutinins in the serum in titres ranging from $1: 20$ to $1: 512$. All the babies with confirmed IRDS had agglutinins in their sera, the titres ranging

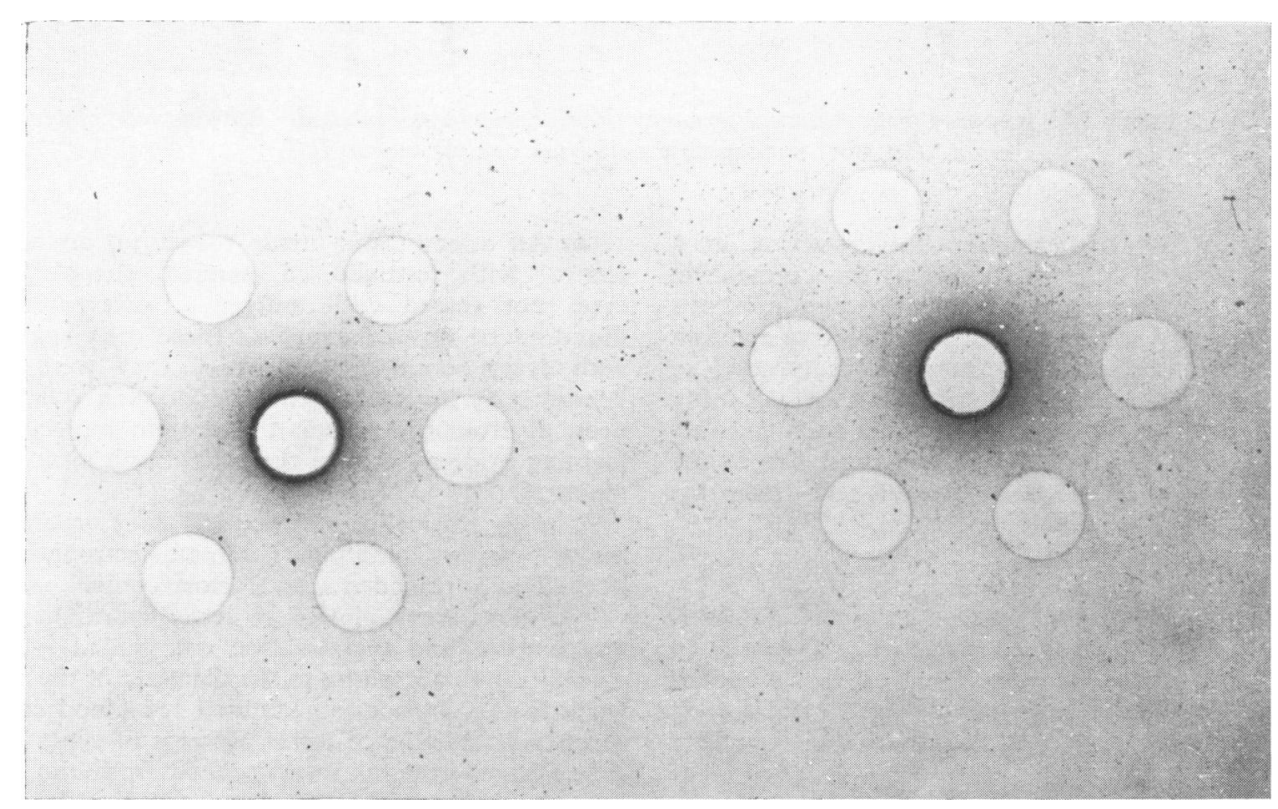

Fig. 4.-Left side: monospecific antiserum against human IgG in central well. Bence-Jones proteins in peripheral wells. Right side: monospecific antiserum against human IgA in central well. Bence-Jones proteins in peripheral wells. 
FIG. 5.-Left side: Bence-Jones proteins in peripheral wells. Monospecific antiserum against Bence-Jones proteins type $K$ in central well. Right side: Bence-Jones proteins in peripheral wells. Monospecific antiserum against Bence-Jones proteins type $L$ in central well.

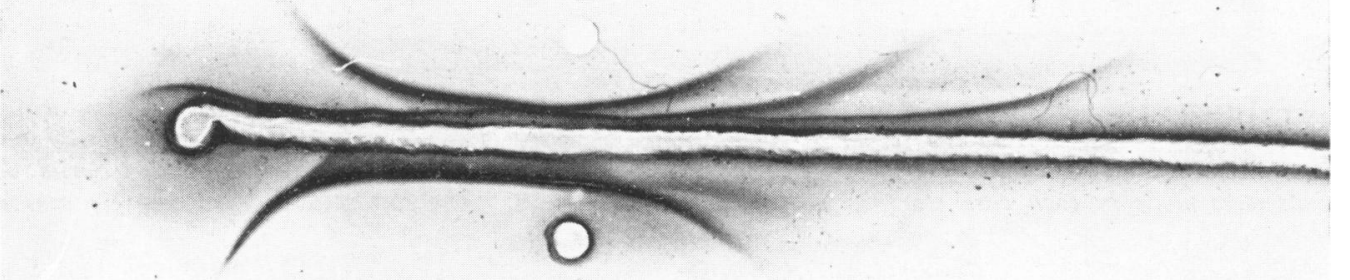

FIG. 6.-Upper well: Papain digest of IgG prepared from pooled human serum. Lower well: IgG prepared from pooled human serum. In slot: Monospecific antiserum against human IgG.

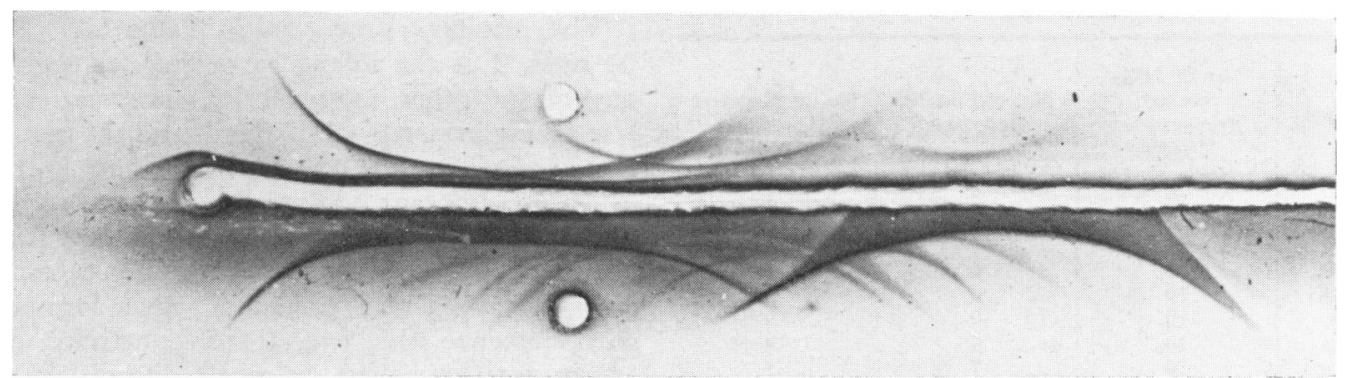

Frg. 7.-Upper well: Papain digest of same IgG preparation. Lower well: pooled human serum. In slot: polyvalent antiserum against whole human serum. 


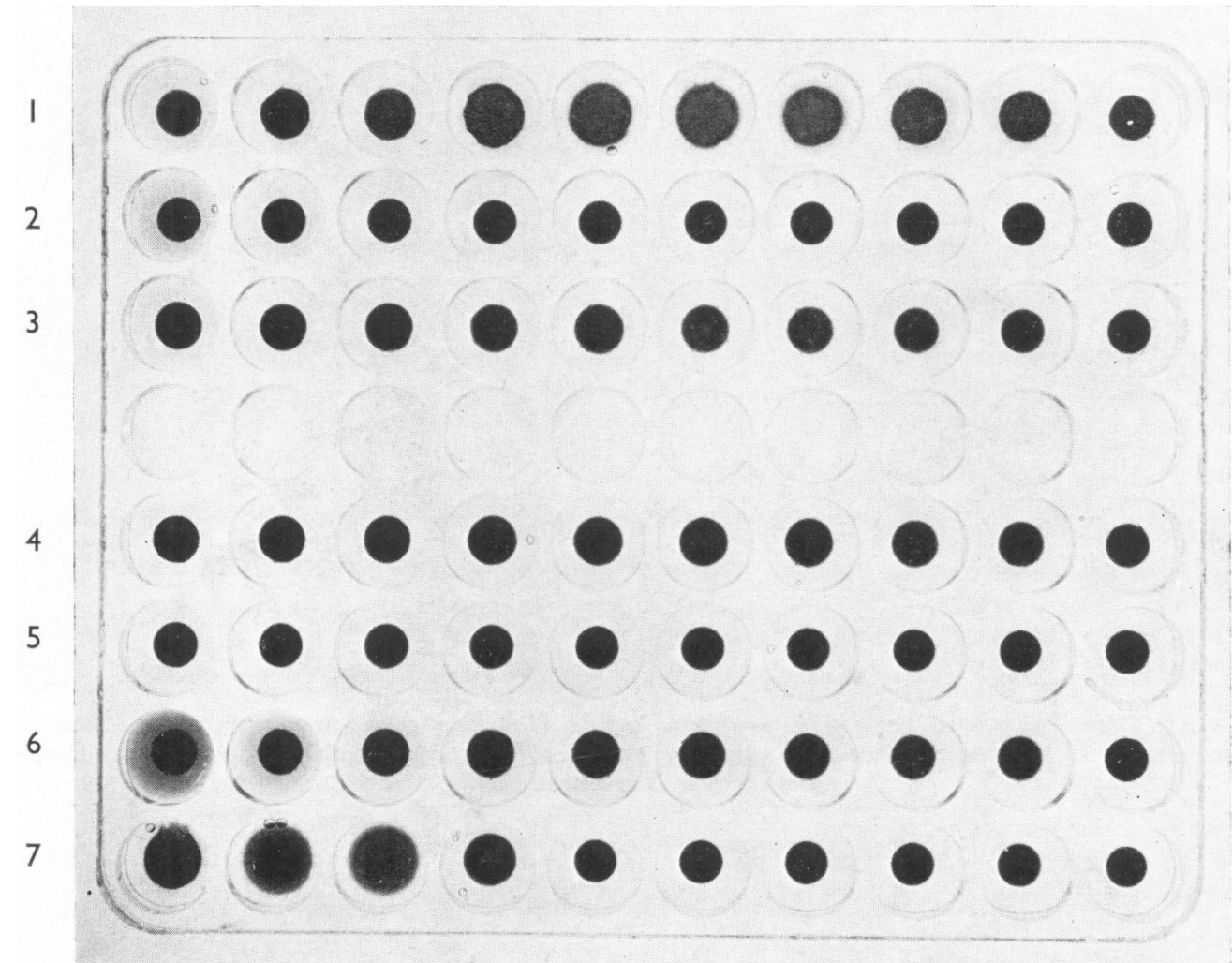

FIG. 8.-Titrations of serum of an infant with IRDS (row 1) and sera of 5 healthy premature infants against cells coated wtih IgG prepared from the serum of each infant's mother. Row 7 contains a titration of a commercial antiserum to human IgG against cells coated with IgG from the mother of the affected infant. Serial doubling dilutions were made in each case starting with a dilution of $1: 10$. The last well in each row contains cells in plain diluent.

\section{TABLE III}

Titrations of Sera of Infants who Possessed Agglutinins against Their Own Mothers' IgG, with Erythrocytes Sensitized with IgG Prepared from Other Maternal Sera

\begin{tabular}{c|c|c|c}
\hline Infant & $\begin{array}{c}\text { No. of IgG- } \\
\text { coated } \\
\text { Preparations } \\
\text { Titrated }\end{array}$ & $\begin{array}{c}\text { No. of Positive } \\
\text { Reactions }\end{array}$ & $\begin{array}{c}\text { No. of Negative } \\
\text { Reactions }\end{array}$ \\
\hline Ho & 11 & 8 & 3 \\
Di & 11 & 0 & 11 \\
FA & 19 & 4 & 15 \\
FB & 18 & 6 & 12 \\
PB & 10 & 6 & 10 \\
Bas & 10 & 0 & 10 \\
Da & 10 & 0 & 3 \\
Bar & 10 & 7 & 5 \\
dKo & 8 & 3 & 0 \\
Ek & 9 & 9 & \\
\hline
\end{tabular}

from $1: 32$ to $1: 5120$. Fig. 8 shows an example of one such titration. In an attempt to assess the specificity of the serological reaction, we titrated 10 infants' sera containing agglutinins against their own mothers' IgG, with IgG prepared from other maternal sera.

The results are recorded in Table III. As can be seen, 3 of the infants' sera did not agglutinate any of the other maternal IgG preparations, one serum agglutinated all of them, and the remaining 6 reacted with some but not all.

To 10 different agglutinating sera we added a monospecific antiserum against IgM and repeated the titration procedure with each after centrifuging and discarding any precipitate that formed. In each instance the agglutinating activity of the serum was abolished or much diminished. The anti-IgM antiserum was monospecific and free from circulating complexes (Fig. 9) (personal 


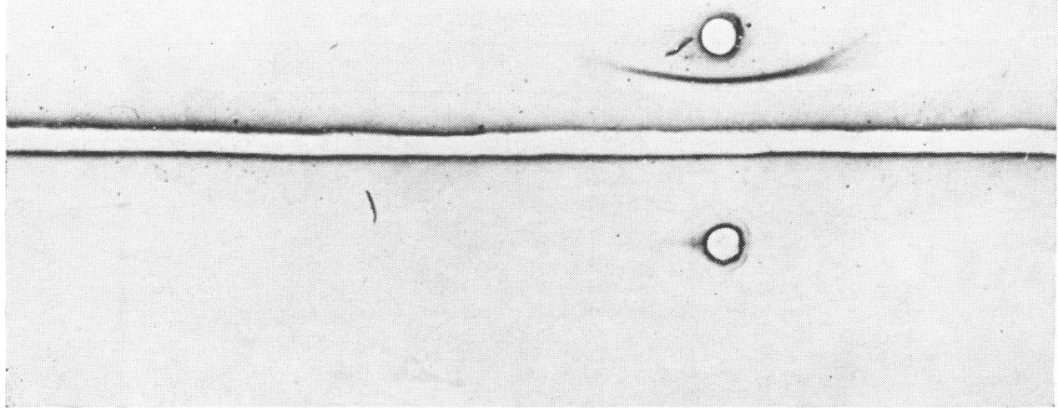

FIG. 9.-Upper well: whole serum from a normal adult man. Lower well: IgG prepared as described before. In slot: Monospecific antiserum against IgM.

communication: Hyland laboratories, 1968). The agglutinating activity of the sera was abolished by incubation with $0.1 \mathrm{M}$ 2-mercapto-ethanol for 2 hours at $37^{\circ} \mathrm{C}$. From these observations we concluded that the agglutinin was in the infant's serum, and was probably of the IgM type.

Sera of 7 infants with IRDS and of 12 normal infants were titrated against red blood cells coated with Bence-Jones proteins of type $\mathrm{K}$ or $\mathrm{L}$. These sera were selected because there was more cord blood available for controlled experiments in these cases. The results are set out in Table IV. A similar experiment was performed using a papain digest of IgG as the antigen. The results are presented in Table V.

The results presented in Tables IV and V indicate that there is no significant difference in the reaction of sera of healthy infants and of infants with IRDS to fragments of the IgG molecule, though the two groups differ considerably in their reaction to the intact protein.

Table VI embodies the results obtained on followup specimens from 4 of the infants who had agglutinins in their cord sera and 2 who did not, at varying intervals after birth. As can be seen, the titre had risen conspicuously in 3 out of the 4

TABLE IV

Agglutinating Activity of Infants' Sera against Maternal IgG and Bence-Jones Proteins of Types $L$ and $K$

\begin{tabular}{|c|c|c|c|c|c|c|c|c|c|c|c|c|c|}
\hline \multicolumn{7}{|c|}{ Normal Infants } & \multicolumn{7}{|c|}{ Infants with IRDS } \\
\hline \multirow[b]{2}{*}{ Infant } & \multicolumn{2}{|c|}{ vs. Maternal IgG } & \multicolumn{2}{|c|}{ vs. Type $\mathrm{K}$} & \multicolumn{2}{|c|}{ vs. Type L } & \multirow[b]{2}{*}{ Infant } & \multicolumn{2}{|c|}{ vs. Maternal IgG } & \multicolumn{2}{|c|}{ vs. Type K } & \multicolumn{2}{|c|}{ vs. Type L } \\
\hline & $\begin{array}{c}\text { Max. } \\
\text { Intensity } \\
\text { Observ- } \\
\text { ed }\end{array}$ & Titre & $\begin{array}{c}\text { Max. } \\
\text { Intensity } \\
\text { Observ- } \\
\text { ed }\end{array}$ & Titre & $\begin{array}{c}\text { Max. } \\
\text { Intensity } \\
\text { Observ- } \\
\text { ed }\end{array}$ & Titre & & $\begin{array}{c}\text { Max. } \\
\text { Intensity } \\
\text { Observ- } \\
\text { ed }\end{array}$ & Titre & $\begin{array}{c}\text { Max. } \\
\text { Intensity } \\
\text { Observ- } \\
\text { ed }\end{array}$ & Titre & $\begin{array}{c}\text { Max. } \\
\text { Intensity } \\
\text { Observ- } \\
\text { ed }\end{array}$ & Titre \\
\hline $\begin{array}{l}\mathrm{Ja} \\
\mathrm{Mo} \\
\mathrm{Ni} \\
\mathrm{We} \\
\mathrm{Jac} \\
\mathrm{Ab} \\
\mathrm{Re} \\
\mathrm{Ba} \\
\mathrm{Jo} \\
\mathrm{Sa} \\
\text { uR } \\
\text { Ro }\end{array}$ & $\begin{array}{c}\overline{-} \\
++ \\
- \\
\overline{-} \\
\overline{-} \\
\overline{-} \\
\overline{+}+ \\
+\end{array}$ & $\begin{array}{c}0 \\
0 \\
1: 160 \\
0 \\
0 \\
0 \\
0 \\
0 \\
0 \\
0 \\
1: 128 \\
0\end{array}$ & $\begin{array}{c}- \\
- \\
++ \\
+ \\
\pm \\
= \\
= \\
+ \\
++ \\
+\end{array}$ & $\begin{array}{cl} & 0 \\
0 \\
1: 320 \\
1: 16 \\
1: 40 \\
0 \\
0 \\
0 \\
1: 40 \\
0 \\
1: 80 \\
1: 80\end{array}$ & $\begin{array}{c}\overline{-} \\
+ \\
+ \\
\overline{-} \\
\pm \\
\overline{ \pm} \\
+ \\
++ \\
+\end{array}$ & $\begin{array}{c}0 \\
1: 40 \\
1: 320 \\
0 \\
0 \\
1: 40 \\
0 \\
0 \\
1: 40 \\
0 \\
1: 80 \\
1: 80\end{array}$ & $\begin{array}{l}\text { Ek } \\
\mathrm{Pr} \\
\mathrm{Bu} \\
\mathrm{Ho} \\
\mathrm{Da} \\
\text { vA } \\
\text { FB }\end{array}$ & $\begin{array}{c}++ \\
+ \\
\pm \\
\pm \\
+ \\
+++ \\
+++\end{array}$ & $\begin{array}{ll}1 & : 320 \\
1 & : 160 \\
1 & : 1024 \\
1 & : 64 \\
1 & : 32 \\
1 & : 80 \\
1 & : 80\end{array}$ & $\begin{array}{c}z \\
z \\
- \\
++ \\
+++ \\
+++\end{array}$ & $\begin{aligned} & 0 \\
& 0 \\
& 0 \\
& 0 \\
& 0 \\
& 1: 160 \\
& 1: 20 \\
& 1: 20\end{aligned}$ & $\begin{array}{c}- \\
+ \\
\pm \\
+ \\
+++ \\
+++ \\
+++\end{array}$ & $\begin{array}{ll} & 0 \\
1 & : 640 \\
1 & : 20 \\
1 & : 10 \\
1 & : 160 \\
1 & : 80 \\
1 & : 80\end{array}$ \\
\hline Mear & res & $1: 24$ & & $1: 48$ & & $1: 50$ & & & $1: 251$ & & $1: 29$ & & $\star_{1}: 141$ \\
\hline
\end{tabular}

* Anti-type L titre higher here, but there is too much scatter for a significant difference. 
TABLE V

Agglutinin Titres of Infants' Sera against Cells Coated with a Papain Digest of IgG

\begin{tabular}{|c|c|c|c|c|c|c|c|c|c|}
\hline & \multirow{2}{*}{ Infant } & \multicolumn{7}{|c|}{ Dilution of Infants' Sera } & \multirow[b]{2}{*}{ Titre } \\
\hline & & $1: 10$ & $1: 20$ & $1: 40$ & $1: 80$ & $1: 160$ & $1: 320$ & $1: 640$ & \\
\hline $\begin{array}{l}\text { Normal } \\
\text { infants }\end{array}$ & $\begin{array}{l}\mathrm{Ja} \\
\mathrm{Ni} \\
\mathrm{Mo} \\
\mathrm{We} \\
\mathrm{Jac} \\
\mathrm{Ab} \\
\mathrm{Re} \\
\mathrm{Ba} \\
\mathrm{Jo} \\
\mathrm{Sa} \\
\text { vR } \\
\mathrm{Ro}\end{array}$ & $\begin{array}{c}- \\
+++ \\
\pm \\
++ \\
- \\
- \\
++ \\
+++ \\
++ \\
+ \\
++ \\
\pm\end{array}$ & $\begin{array}{c}- \\
+++ \\
\pm \\
++ \\
- \\
\pm \\
+++ \\
+++ \\
+++ \\
++ \\
++ \\
+\end{array}$ & $\begin{array}{c}- \\
+++ \\
- \\
+ \\
- \\
+ \\
+++ \\
+++ \\
+++ \\
++ \\
++ \\
+\end{array}$ & $\begin{array}{c}- \\
+++ \\
- \\
\pm \\
- \\
\pm \\
+++ \\
+++ \\
+++ \\
\pm \\
+++ \\
\pm\end{array}$ & $\begin{array}{c}- \\
++ \\
- \\
- \\
- \\
- \\
+++ \\
+++ \\
+++ \\
- \\
++ \\
-\end{array}$ & $\begin{array}{c}- \\
+ \\
- \\
- \\
- \\
- \\
+ \\
+++ \\
+++ \\
- \\
++ \\
-\end{array}$ & $\begin{array}{l}- \\
- \\
- \\
- \\
- \\
- \\
- \\
+ \\
+ \\
- \\
\pm \\
-\end{array}$ & $\begin{array}{ll} & 0 \\
1 & : 320 \\
1 & : 20 \\
1 & : 80 \\
& 0 \\
1 & : 80 \\
1 & : 320 \\
1 & : 640 \\
1 & : 640 \\
1 & : 80 \\
1 & : 640 \\
1 & : 80\end{array}$ \\
\hline & Mean & & & & & & & & $1: 242$ \\
\hline $\begin{array}{l}\text { Infants } \\
\text { with } \\
\text { IRDS }\end{array}$ & $\begin{array}{l}\text { Ek } \\
\text { Pr } \\
\text { Bu } \\
\text { Ho } \\
\text { Da } \\
\text { vA } \\
\text { FB }\end{array}$ & $\begin{array}{c}+++ \\
+++ \\
- \\
\pm \\
\pm \\
- \\
-\end{array}$ & $\begin{array}{c}++ \\
+++ \\
- \\
- \\
\pm \\
- \\
-\end{array}$ & $\begin{array}{c}+++ \\
+++ \\
- \\
- \\
+ \\
-\end{array}$ & $\begin{array}{c}+++ \\
+++ \\
- \\
- \\
\pm \\
- \\
-\end{array}$ & $\begin{array}{c}++ \\
++ \\
- \\
- \\
- \\
- \\
-\end{array}$ & $\begin{array}{c}++ \\
+ \\
- \\
- \\
- \\
- \\
-\end{array}$ & $\begin{array}{l}+ \\
- \\
- \\
- \\
- \\
-\end{array}$ & $\begin{aligned} 1 & : 1280 \\
1 & : 320 \\
& 0 \\
1 & : 10 \\
1 & : 80 \\
& 0 \\
& 0\end{aligned}$ \\
\hline & Mean & & & & & & & & $1: 241$ \\
\hline & $\begin{array}{l}\text { Control } \\
\text { commercial } \\
\text { anti- } \\
\text { serum }\end{array}$ & - & - & \pm & + & + & \pm & - & \\
\hline
\end{tabular}

TABLE VI

Anti-IgG Titres in Follow-up Specimens, as compared with Titres in Cord Serum

\begin{tabular}{|c|c|c|c|c|}
\hline & Infant & Titre of Anti-IgG in Cord Sera & $\begin{array}{c}\text { Age at Which Follow-up Speci- } \\
\text { men was Obtained (days) }\end{array}$ & $\begin{array}{c}\text { Anti-IgG Titre of Follow-up } \\
\text { Specimen }\end{array}$ \\
\hline IRDS & $\begin{array}{l}\text { Ek } \\
\mathrm{Pr} \\
\mathrm{Da} \\
\mathrm{dK}\end{array}$ & $\begin{array}{l}1: 64 \\
1: 32 \\
1: 64 \\
1: 80\end{array}$ & $\begin{array}{r}14 \\
15 \\
40 \\
2\end{array}$ & $\begin{array}{ll}1 & : 640 \\
1 & : 256 \\
1 & : 1024 \\
1 & : 80\end{array}$ \\
\hline Normal & $\begin{array}{l}\text { Ja } \\
\text { Mo }\end{array}$ & $\begin{array}{l}0 \\
0\end{array}$ & $\begin{array}{l}14 \\
30\end{array}$ & $\begin{array}{l}\mathbf{0} \\
\mathbf{0}\end{array}$ \\
\hline
\end{tabular}

cases of IRDS-the fourth infant died at 2 days of age. Healthy infants had no agglutinins in the follow-up specimens.

\section{Discussion}

It is generally accepted that the fetus in utero normally synthesizes only very small quantities of immunoglobulins, mainly IgM. Mårtensson and Fudenberg (1965) demonstrated that some IgG was formed by the fetus and would cross the placenta to enter the maternal circulation, but nearly all of the IgG present in the infant's serum at birth was of maternal origin and had been actively and selectively transferred by the placenta
(Gitlin et al., 1964). IgM is unable to cross the placenta in either direction (Gitlin et al., 1964; Epstein, 1965). The quantities of immunoglobulins synthesized by the fetus are dependent on antigenic stimulation, and, if suitably challenged, the fetus will respond by increasing its rate of production of immunoglobulins. At first, antibodies of the IgM type are formed, as was shown by Koltay and Illyés (1966), who found raised levels of IgM and lowered IgG in patients with interstitial plasma cellular pneumonia. Later, antibodies of the IgG type are also synthesized. Results presented in this paper confirm our earlier findings (Hardie et al., 1965; Hardie et al., 1968), 
and indicate that infants with IRDS are producing agglutinating antibodies that are probably of the IgM type and capable of combining with intact maternal IgG molecules. It is this capacity for reacting against the intact IgG molecule as opposed to its fragments which clearly distinguishes the IRDS group from the normal controls. This is unlikely to be a non-specific antiglobulin reaction, as, with the exception of two cases, the sera reacted with a proportion only or with none of the cells coated with foreign maternal IgG. The fact that the sera which agglutinated IgG-coated cells did not react with albumin-coated cells implies that the agglutinins were not directed at antigenic groupings on the membranes of the formalinized tanned sheep cells themselves. Steinberg (1962), and Steinberg and Wilson (1963) investigated a large number of cord blood sera from clinically normal infants, using the standard Ragg and Snagg typing sera, but found no agglutinins directed against the known antigenic determinants on the IgG molecule in any instance. A possible explanation for this is that the agglutinins found in the sera investigated by us are directed against some, as yet unidentified, antigenic determinant. It may be relevant that certain adults have been observed to have in their sera agglutinins against genetically foreign IgG allotypes, despite the fact that they have never received blood transfusions or pooled $\gamma$-globulins by injection (Harboe, Rau, and Aho, 1965). In a study of such individuals (Steinberg and Wilson, 1963) it was found that, in each instance, the mother of that individual had present on her IgG molecules the determinant(s) against which the agglutinins were directed.

A large proportion of the infants (healthy and with IRDS) studied by us had agglutinins against IgG fragments. This is in accordance with the results obtained by Epstein (1965) in his study of agglutinins against Bence-Jones proteins in the cord sera of healthy infants. The presence of similar agglutinins has been shown in most normal adult sera, the incidence increasing with age. The function of these may be to remove the endproducts of IgG catabolism or of immune reactions from the circulating blood.

Our findings are consistent with the idea that an immune reaction takes place in IRDS and that the maternal IgG is the antigen.

\section{Summary}

Sheep red blood cells were formalinized, tanned, and coated with IgG prepared from each of 63 maternal sera. The sera were collected from mothers of 35 healthy premature infants, of 11 patients with the idiopathic respiratory distress syndrome (IRDS) confirmed by chest $x$-ray, and of 17 babies diagnosed as having respiratory distress, on clinical grounds, but without radiological confirmation. The sensitized sheep cells were titrated against serial doubling dilutions of the infants' sera. Similar titrations were performed using cells sensitized with Bence-Jones proteins or with a papain digest of IgG. Concentrations of total serum proteins, IgG, and IgM in the infant's serum were determined in each case.

(1) Sera of all infants with IRDS confirmed radiologically contained agglutinins against their mothers' IgG coated on sheep red blood cells.

(2) A small proportion of healthy premature infants possessed similar agglutinins.

(3) Healthy premature infants and infants with the IRDS had similar titres of serum agglutinins against papain-digested IgG and against BenceJones proteins.

(4) Infants suffering from IRDS had significantly lower concentrations of total serum proteins and of IgG than had healthy infants of the same estimated gestational age.

We are grateful to Dr. Max Klein of the Department of Child Health for co-operation in the diagnosis and management of our patients. We are indebted to Dr. G. M. Potgieter of the Department of Chemical Pathology for the gift of the Bence-Jones proteins and for much valuable advice. We wish to thank Professor A. Kipps and Dr. B. W. Russell of the Virus Research Unit for help concerning the passive haemagglutination technique, and Dr. M. C. Botha of the Blood Transfusion Service for kindly providing the cord blood sera. Dr. Tappick of the City of Cape Town Abattoirs provided us with generous supplies of sheep's blood. Thanks are also due to Dr. J. G. Burger, Superintendent of Groote Schuur Hospital, for permission to publish.

\section{REFERENCES}

Cox, C. D. (1956). Preservation of sheep erythrocytes and their use in a rapid plate titration of heterophilic antibodies in infectious mononucleosis. F. Lab. clin. Med., 48, 298.

Csizmas, L. (1960). Preparation of formalinized erythrocytes. Proc. Soc. exp. Biol. (N.Y.), 103, 157.

Daniel, T. M., and Stavitsky, A. B. (1964). Passive hemagglutination in study of antigens and antibodies. Meth. med. Res., $10,155$.

-, Weyand J. G. M., Jr., and Stavitsky, A. B. (1963). Micromethods for the study of proteins and antibodies. IV. Factors involved in protein-sensitized erythrocytes for detection of antigen and antibody. $\mathcal{F}$. Immunol., 90, 741

Epstein, W. V. (1965). Specificity of macroglobulin antibodies synthesized by the normal human fetus. Science, 148, 1591.

Gitlin, D., and Boesman, M. (1966). Serum $\alpha$-fetoprotein, albumin, and $\gamma-\mathrm{G}$-globulin in the human conceptus. $\mathcal{f}$. clin. Invest., $45,1826$.

- Kumate, J., Urrusti, J., and Morales, C. (1964). The selectivity of the human placenta in the transfer of plasma proteins from mother to fetus. ibid., 43, 1938.

Gornall, A. G., Bardawill, C. J., and David, M. M. (1949). Determination of serum proteins by means of the biuret reaction. f. biol. Chem., 177, 751 . 
Harboe, M., Rau, B., and Aho, K. (1965). Properties of various anti- $\gamma$-globulin factors in human sera. F. exp. Med., 121, 503.

Hardie, G., Harrison, V. C., and Kench, J. E. (1968). Further observations on serum proteins in respiratory distress syndrome of the newborn. Arch. Dis. Childh., 43, 471.

—, Heese, H. de V., and Kench, J. E. (1965). Serum proteins in the idiopathic respiratory distress syndrome of the newborn Lancet, 2, 876.

, and Kench, J. E. (1967). Maternal serum-proteins in idiopathic respiratory distress syndrome of the newborn. ibid., 1, 809 .

Hořejši, J., and Smetana, R. (1956). The isolation of gammaglobulin from blood-serum by rivanol. Acta med. scand., $45,65$.

Kistler, P., Nitschmann, H., Wyttenbach, A., Studer, M., Niederöst, C., and Mauerhofer, M. (1960). Humanes Siderophilin: Isolierung mittels Rivanol aus Blutplasma und Plasma Fractionen, analytische Bestimmung und Kristallisation. Vox Sang. (Basel), 5, 403.

Koltay, M., and Illyés, M. (1966). A study of immunoglobulins in the blood serum of infants with interstitial plasma cellular pneumonia. Acta paediat. (Scand.), 55, 489.
Mártensson, L., and Fudenberg, H. H. (1965). Gm genes and rG-globulin synthesis in the human fetus. f. Immunol., 94, 514.

Moskowitz, M., and Carb, C. (1957). Surface alteration and the agglutinability of red cells. Nature (Lond.), 180, 1049.

Porter, R. R. (1959). The hydrolysis of rabbit $\gamma$-globulin and antibodies with crystalline papain. Biochem. F., 73, 119.

Saifer, A., and Lipkin, L. E. (1959). Electrophoretic and immunologic studies of rivanol-fractionated serum proteins. Proc. Soc. exp. Biol. (N.Y.), 102, 220.

Steinberg, A. G. (1962). Progress in the study of genetically determined human gamma globulin types (the $\mathrm{Gm}$ and Inv groups). Prog. med. Genet., 2, 1.

—, and Wilson, J. A. (1963). Hereditary globulin factors and immune tolerance in man. Science, 140, 303.

Correspondence to Professor J. E. Kench, C.S.I.R. Protein Research Unit, Department of Chemical Pathology, Medical School, University of Cape Town, South Africa. 